\title{
Aplikasi Syariat Dalam Bisnis
}

\author{
Hedher Tuakia \\ Dosen STIE Malangkucecwara \\ Jalan Terusan Candi Kalasan Malang \\ Telp. (0341) 491813
}

\begin{abstract}
:
Today there is a transition point of view to the conception of business / business. Some businesspeople no longer rely solely on the economic system adopted by capitalism (conventional) but also begin to direct their point of view on the economic / business system that can give satisfaction to the spiritual aspects or the satisfaction of the human mind. The traders in running their business do not merely get the highest material benefits, but they also want to get satisfaction. This is indicated by the adamnya sense of satisfaction if ternayata in running the business can be beneficial to the surrounding environment and for the purposes of social interaction. be friendly and tolerant to others and want to establish brotherhood among fellow traders and the surrounding community. That the motive or intention of the merchants in his business is to seek the blessing or pleasure of Allah SWT. Not just to maximize profits, as adopted by the conventional economic system. They practice what Rasulullah SAW has exemplified in his business by always being honest, trustful and tolerant.

Keywords: Sharia Business
\end{abstract}

\section{PENDAHULUAN}

Dewasa ini terjadi peralihan sudut pandang terhadap konsepsi bisnis/usaha. Sebagian pebisnis tidak lagi hanya bertumpu pada sistem ekonomi yang dianut oleh kapitalisme (konvensional) tetapi juga mulai mengarahkan sudut pandangnya pada sistem ekonomi/usaha yang bisa memberi kepuasan pada aspek-aspek spiritual atau kepuasan batin manusia. Perubahan sudut pandang ini membawa pengaruh pada perubahan motif didalam bisnis usaha. Motif memaksimilisasi kepuasan dan maksimalisasi keuntungan yang menjadi pendorong utama sekaligus tujuan dari keputusan ekonomi dalam pandangan ekonomi konvensional bukannya salah ataupun dilarang di dalam Islam. Islam ingin mendudukkannya pada posisi yang benar, yakni semua itu dalam rangka maksimalisasi dan keuntungan di akhirat (Nasution, Mustafa dkk, 2006).

Kegiatan usaha yang hanya bermotif pada keuntungan yang maksimal sesungguhnya merupakan sesuatu yang absurd (tidak masuk akal), motif maksimal sendiri sebagai tujuan dan teori produksi dalam ekonomi konvensional merupakan konsep yang absurd. Secara teoritis memng dapat dihitung pada keadaan bagaimana keuntungan maksimal yang dicapai. Akan 
tetapi dalam praktik, tak seorangpun mengetahui apakah pada saat tertentu ia sedang, sudah atau bahkan belum mencapai keuntungan maksimal. Dalam ekonomi konvensionalpun diakui bahwa keadaan keseimbangan dalam pasar bebas dimana semua perusahaan berada dalam keadaan 'normal profit' hanya tercapai dalam jangka panjang. Implikasi dari absurditas konsep itu adalah ia hanya bisa dijadikan acuan tehnis, tetapi tidak dapat dijadikan patokan perilaku. Bahkan sebagai acuan tehnispun masih belum sempurna akibat perbedaan ukuran kebenaran yang digunakan yakni kebenaran logika bukanlah kebenaran Allah (Nasution, Mustafa dkk, 2006).

Islam mengajarkan bahwa kebenaran hanya datang dari Allah dan manusia tidak boleh ragu terhadap kebenaran Allah. "Kebenaran itu dari Allah dan jangan kalian manusia itu ragu terhadap kebenaran Allah”. Umar Chapra dalam kontek ini mengatakan ketidak konsistenan antara tujuan dengan mekanismenya. Dalam ilmu ekonomi konvensional, antara ekonomi positif (positive economics) dan ekonomi normatif (normative ekonomics) secara konseptual sudah dibedakan sejak awal, yang mana merupakan pengakuan bahwa ekonomi positif yang mereka tawarkan tidak dapat menjawab tujuantujuan yang seharusnya dicapai dalam ekonomi normatif (Nasution, Mustafa dkk, 2006).

Setiap manusia menurut pandangan Islam memerlukan harta untuk mencukupi segala kebutuhan hidupnya. Karenanya manusia akan selalu berusaha untuk memperoleh harta kekayaan itu. Salah satunya adalah melalui bekerja, sedangkan salah satu dari ragam bekerja adalah berbisnis. Islam mewajibkan setiap muslim khususnya yang memiliki tanggungan untuk bekerja. Bekerja menjadi sebab pokok yang memungkinkan manusia memiliki harta kekayaan. Allah memberikan kemungkinan kepada manusia untuk mencari rezeki dengan menyediakan berbagai fasilitas yang dapat dimanfaatkan manusia untuk mencari rezeki. Allah SWT menjelaskan tentang hal ini di dlam banyak ayat al-Quran, seperti: “.... Dan, Dia telah memberikan kepadamu (keperluanmu) dari segala apa yang kamu mohonkan kepadaNya. Dan jika kamu menghitung nikmat Allah, tidaklah dapat kamu menghitungkannya...." (Ibrahim: 34). "Dialah yang menjadikan bumi ini mudah bagi kamu, maka berjalanlah di segala penjurunya dan makanlah sebagian dari rezekiNya" (al-Mulk: 29). "Sesungguhnya, Kami telah menempatkan kamu sekalian di bumi dan Kami adakan bagimu di muka bumi itu sumber-sumber penghidupan... " (al-A'raf: 10)

“... Dia (Allah) telah menciptakan kalian dari bumi (tanah) dan menjadikan kamu pemakmurnya..."(Huud: 61)

Ayat-ayat Allah yang mulia ini menjelaskan bahwa Allah telah melengkapi berbagai sumber daya di dalam bumi ini demi pemenuhan kebutuhan hidup manusia. Allah menyediakan itu semua dalam rangka manusia mencari 
rezeki dan memakmurkan bumi. Di dalam mencari rezeki, Islam sangat menekankan (mewajibkan) aspek kehalalannya, baik dari segi perolehan maupun pendayagunaannya (pengelolaan dan pembelanjaan). Perhatikan misalnya ayat Allah: "Makanlah dari rezeki Allah yang halal dan baik" (...) “... Dan janganlah kalian berbuat israf (menafkahkan harta di jalan kemaksiatan). Sesungguhnya Allah tidak menyukai orang-orang yang membuat Israf" (al-An'aam :141). "Kedua telapak kaki seorang anak Adam di hari kiamat masih belum beranjak sebelum ditanyakan kepadanya mengenai lima perkara: tentang umurnya, apa yang dilakukannya; tentang masa mudanya, apa yang dilakukannya; tentang hartanya, dari mana dia peroleh dan untuk apa dia belanjakannya; dan tentang ilmunya, apa yang dia kerjakan dengan ilmunya itu"(Hadits Riwayat Ahmad)

Sejalan dengan kaidah ushul "al-ashlu fi al-af'al at-taqayyud bil hukmi syar' $i$ ", yang berarti bbahwa hukum asal suatu perbuatan adalah terikat dengan hukum syara': wajib, sunnah, mubah, makruh dan haram. Maka pelaksanaan bisnis harus tetap berpegang teguh pada atau ketentuan syari'at. Dengan demikian menjadi tuntutan bahwa tujuan (orientasi) bisnispun harus disesuaikan dengan bisnis yang Islami. Para ahli Ekonomi Islam merumuskan bahwa bisnis Islam bertujuan untuk mencapai empat hal utama: (1) Target hasil: profit-materi dan benefit-nonmateri; (2) Pertumbuhan, (terus meningkat); (3) Keberlangsungan, dalam kurun waktu selama mungkin, dan (4) Keberkahan atau keridhaan Allah. (Yusanto, Muhamad, 2002).

Tujuan atau orientasi bisnis tersebut merupakan kendali atu sistem kontrol dalam menjalankan bisnis / usaha yang berdasarkan syariat Islam. Kendali Sistem kendali atau sistem kontrol (control system) di sini dimaknai sebagai suatu alat (kumpulan alat) untuk mengendalikan, memerintah, dan mengatur keadaan dari suatu sistem. Pengendalian Manajemen juga menyangkut semua metode, prosedur dan strategi organisasi, termasuk sistem pengendalian manajemen yang digunakan oleh manajemen untuk menjamin bahwa pelaksanaan sesuai dengan strategi dan kebijakan perusahaan.

Adapun fungsi pengendalian manajemen adalah pengukuran dalam perbaikan terhadap pelaksanaan tujuan dan rencana perusahaan dapat dicapai. Pengendalian manajemen juga dapat berfungsi untuk mengembangkan dan merevisi norma-norma (standard) yang memuaskan sebagai ukuran pelaksanaan dan menyediakan pedoman serta bantuan kepada para anggota manajemen yang lain dalam menjamin adanya penyesuaian hasil pelaksanaan yang sebenarnya terhadap norma standard. Disini pengendalian manajemen mencoba agar pelaksanaan sesuai dan cocok dengan rencana atau standard. Kendali bisnis juga menyediakan 
informasi yang akan digunakan oleh pimpinan fungsional untuk mencapai pelaksanaan yang diharuskan

\section{TINJAUAN PUSTAKA}

\section{Kajian Teoritis}

Diskusi tentang tentang bisnis/ekonomi Islam menjadi sesuatu yang menarik. Sebagian pedangan mulai juga mengalihkan sudut pandang didalam usahanya dengan tidak hanya mengejar keuntungan materi (profitmaterial) tetapi juga mulai memperhatikan persoalan kepuasan batin atau rohani (benefid-non material).

Kegiatan usaha yang hanya bermotif pada keuntungan yang maksimal sesungguhnya merupakan sesuatu yang absurd (tidak masuk akal), motif maksimal sendiri sebagai tujuan dan teori produksi dalam ekonomi konvensional merupakan konsep yang absurd. Secara teoritis memng dapat dihitung pada keadaan bagaimana keuntungan maksimal ang dicapai. Akan tetapi dalam praktik, tak seorangpun mengetahui apakah pada saat tertentu ia sedang, sudah atau bahkan belum mencapai keuntungan maksimal. Dalam ekonomi konvensionalpun diakui bahwa keadaan keseimbangan dalam pasar bebas dimana semua perusahaan berada dalam keadaan 'normal profit' hanya tercapai dalam jangka panjang. Implikasi dari absurditas konsep itu adalah ia hanya bisa dijadikan acuan tehnis, tetapi tidak dapat dijadikan patokan perilaku. Bahkan sebagai acuan tehnis pun masih belum sempurna akibat perbedaan ukuran kebenaran yang digunakan yakni kebenaran logika bukanlah kebenaran Allah (Nasution, Mustafa dkk, 2006).

Dengan Kendali syari'at , bisnis bertujuan untuk mencapai empat hal utama: (1) Target hasil: profit-materi dan benefit-nonmateri, (2) Pertumbuhan, terus meningkat. (3) Keberlangsungan, dalam kurun waktu selama mungkin. (4) Keberkahan atau keridhaan Allah. (Yusanto, Muhammad, 2002).

\section{Target Hasil : Profit-materi dan Benefit-non Materi:}

Tujuan Perusahaan harus hanya untuk mencari profit (qimah madiyah atau nilai materi) setingginya, tetapi harus dapat memperoleh dan memberikan benefit (keuntungan atau manfaat) non materi kepada internal organisasi perusahaan dan eksternal (lingkungan), seperti terciptanya suasana persaudaraan, kepedulian sosial, dan sebagainya.

\section{Pertumbuhan}

Jika profit materi dan benefit non materi telah diraih sesuai target, perusahaan akan mengupayakan pertumbuhan atau kenaikan terus menerus dari setiap profit dan benefitnya itu. Hasil perusahaan akan terus diupayakan agar tumbuh meningkat setiap tahunnya. Upaya penumbuhan ini tentu dijalankan dengan koridor syariat Islam. 


\section{Keberlangsungan}

Belum sempurna orientasi manajemen suatu perusahaan bila hanya berhenti pada pencapaian target hasil dan pertumbuhan. Karena itu perlu diupayakan terus agar pertumbuhan target hasil yang telah diraih dapat dijaga keberlangsungannya dalam kurun waktu yang cukup lama. Sebagaimana upaya pertumbuhan, setiap aktivitas untuk menjaga keberlangsungan tersebut juga dijalankan dalam koridor syariah.

\section{Keberkahan}

Faktor keberkahan atau orientasi untuk menggapai ridha Allah SWT merupakan puncak kebahagiaan hidup seorang muslim. Bila ini tercapai, menandakan terpenuhinya dua syarat, diterimanya amal manusia, yakni adanya elemen niat yang ikhlas dan cara yang sesuai dengan tuntunan syari'at. Karenanya, para pengelola bisnis perlu mematok orientasi keberkahan yang dimaksud agar pencapaian segala orientasi di atas senangtiasa berada dalam koridor syari'at yang menjamin diraihnya keridhaan Allah SWT. (Yusanto, Muhammad, 2002)

Dari paparan diatas, jelaslah bahwa orientasi bisnis Islam harus didasarkan pada pengabdian kepada Allah. Hal ini sebagaimana dinyatakan di dalam alQuran Adz-Dzariyah: 56). "Dan Aku tidak menciptakan jin dan manusia melainkan agar beribadah kepada-Ku” (Shihab, M.Quraish, 2009). Motif dalam produksi dalam konteks Islam bukanlah pada memaksimilisasi kepuasan dan maksimalisasi keuntungan yang menjadi pendorong utama sekaligus tujuan dari keputusan ekonomi dalam pandangan ekonomi konvensional bukannya salah ataupun dilarang di dalam Islam. Islam ingin mendudukkannya pada posisi yang benar, yakni semua itu dalam rangka maksimalisasi dan keuntungan di akhirat (Nasution, Mustafa dkk, 2006).

Pandangan ini sesuai dengn apa yang diisyaratkan Allah di dalam firmanNya Surat Hud ayat 15-16: "Baraangsiapa yang menghendaki kehidupan dunia dan perhiasannya, niscaya niscaya kami sempurnakan bagi mereka pekerjaan-pekerjaan mereka di sana dan mereka di sana tidk akan dirugikan. Itulah orang-orang yang tiada bagi mereka di akhirat kecuali neraka dan lenyaplah apa yang telah mereka usahakan di sini, dan siasialah apa yang senantiasa mereka kerjakan" (Shihab, M.Quraish, 2009). Ayat ini menekankan bahwa motif dalam usaha manusia haruslah diarahkan tidak hanya untuk mencapai keuntungan / kepuasan dunia saja, tetapi juga harus lebih-lebih untuk mencapai kepentingan akhirat.

\section{METODE PENELITIAN}

\section{Jenis Penelitian}

Jenis penelitian yang dilakukan termasuk jenis penelitian Kualitatif, dalam kaitannya dengan penelitian ini, penggunaan metode kualitatif didasarkan 
pada pertimbangan bahwa peneliti ingin memperoleh informasi yang jelas dan akurat (Moleong, Lexy J, 2011), tentang ada atau tidaknya orientasi syari'at Islam dari para pedagang asongan di sekitar Pasar Belimbing Kota Malang, berikut apa yang dilakukan dalam kaitannya dengan orientasi syariat dalam melaksanakan bisnis / usaha. Dan, bagaimana makna Orientasi Syari'at ini didalam kaitan dengan kendali bisnis atau usaha pedagang Asongan. Selanjutnya peneliti berusaha mendiskripsikan atau menggambarkan fenomena, fakta atau hubungan antar fenomena yang diteliti dengan sistematis, sehingga memberikan gambaran yang akurat tentang permasalahan penelitian.

\section{Lokasi Penelitian}

Penelitian ini dilakukan di sekitar Pasar Blimbing yang lokasinya secara geografis berada wilayah Kecamatan Blimbing Kota Malang. Pemilihan lokasi dilakukan secara sengaja dikarenakan oleh beberapa pertimbangan dan karakteristik pasar Blimbing. Pasar Blimbing ini memiliki lokasi geografis yang menarik untuk dikaji karena berada di Jalan Raya Provinsi, sekitarnya dihuni oleh masyarakat kota (sebagai pendatang baru di lokasi) dan sebagaian lain masih menerapkan pola kehidupan pedesaan. Sehingga secara tidak langsung dapat mencerminkan tingkat konsentrasi kegiatan dan fasilitas perkotaan dan pedesaan. Di sekitar pasar terdapat beberapa Perguruan Tinggi dan Sekolah Menegah Umum (SMU), terdapat banyak hunian mahasiswa dan siswa yang menyewa tempat tinggal dan sudah tentu hal ini akan menjadi konsumen pasar yang cukup tinggi. Secara kebetulan peneliti adalah warga kota Malang, yang berdomisili di Kecamatan Lowokwaru, tetapi bekerja di sekitar pasar sehingga akan lebih mengetahui seluk-beluk secara mendalam kondisi pasar Blimbing.

\section{Fokus Penelitian}

Fokus penelitian akan memberikan arahan agar peneliti terhindar dari pengumpulan data yang tidak perlu dan dijadikan sarana untuk memandu dan mengarahkan jalannya penelitian. Moleong menyatakan bahwa "pada dasarnya penelitian kualitatif tidak di mulai dari sesuatu yang 'kosong', tetapi dilakukan berdasarkan persepsi seseorang terhadap adanya suatu masalah. Masalah dalam penelitian kualitatif dinamakan focus". Dengan bimbingan dan arahan suatu fokus, seorang peneliti tahu persis data mana yang perlu dikumpulkan dan data mana pula yang walaupun mungkin menarik, karena tidak relevan, tidak perlu dimasukkan ke dalam sejumlah data yang sedang dikumpulkan (Moleong, Lexy J, 2000)

Fokus penelitian ini adalah: Bagaimana orientasi Syariat Islam dari pedagang Asongan di sekitar pasar Belimbing, Bentuk - tindakan yang diwujudkan dalam kontek Orientasi syari'at dan bagaimana makna orientasi syari'at dalam mengendalikan bisnis atau usaha pedagang. Dengan fokus 
penelitian ini, peneliti hanya mengcoper data yang menyangkut Orientasi syari'at para pedagang asongan, bentuk tindakan yang sesuai dengan kebutuhan. Dalam penelitian ini sesungguhnya data yang hanya terkait Orientasi atau tujuan Bisnis Islam yang meliputi data tentang: Orientasi Target hasil ( profit materi dan benefid non materi), Orientasi pertumbuhan usaha, orientasi kelangsungan usaha dan orientasi keberkahan.

\section{Jenis dan Sumber Data Penelitian}

Jenis data dalam penelitian ini terdiri dua jenis yaitu: data kualitatif dan data kuantitatif. Data kualitatif adalah data yang berbentuk kata, kalimat, skema dan gambar. Dalam penelitian ini jenis data kualitatif berupa data dalam bentuk hasil interview dengan informan yang diteliti, dan gambar lokasi penelitian yakni Pasar Blimbing Kota Malang. Sedangkan data kuantitatif adalah jenis data yang berbentuk angka atau data kualitatif yang diangkakan, misalnya terdapat dalam skala pengukuran. Dalam penelitian ini jenis data kuantitatif adalah data untuk mendapatkan gambaran tentang jumlah penduduk dan pedagang asongan yang ada di sekitar pasar Blimbing.

\section{Instrumen Penelitian}

Dalam penelitian kualitatif, manusia atau peneliti bertindak sebagai instrumen penelitian, karena ia menjadi segalanya dari keseluruhan proses penelitian, artinya peneliti sekaligus merupakan perencana, pelaksana pengumpulan data, analisis, penafsir data dan pada akhirnya menjadi pelapor hasil penelitiannya. Instrumen dalam penelitian ini sebagai berikut: peneliti sendiri, pedoman interview, dan perekam suara.

\section{Analisis Data}

Analisa data dalam penelitian ini dikerjakan sejak di lapangan, dengan mengolah data menjadi pola-pola berbagai kategori. Data dalam bentuk ungkapan, pengalaman sehari-hari, atau kasus yang telah dikumpulkan disatukan dalam susunan yang dapat menggambarkan pola-pola perilaku atau respon masyarakat secara tipikal. Hal ini peneliti lakukan ketika peneliti benar-benar telah memperoleh kepercayaan subyek, sehingga mereka bersedia mengungkapkan sejumlah pengalaman, pengetahuan, dan pemaknaan terhadap sejumlah realitas yang terkait dengan Orientasi syari'at dalam pelaksanaan usaha/ bisnis.

Untuk mensistimatisasi data yang terkumpul peneliti melakukan 3 (tiga) langkah sebagaimana yang ditawarkan oleh Mils dan Huberman, yang terdiri dari tiga alur kegiatan yang terjadi secara bersamaan yaitu: (1) Reduksi data, (2) Penyajian data, dan (3) Penarikan kesimpulan/verifikasi, dengan menggunakan analisis model interaktif dengan tiga prosedur, yaitu: 


\section{Reduksi Data}

Reduksi data dimaksudkan sebagai proses pemilihan, pemusatan perhatian pada penyederhanaan, pengabstrakkan dan transformasi data "kasar" yang muncul dari catatan-catatan tertulis di lapangan. Proses reduksi dalam penelitian ini bertujuan menggolongkan, mangarahkan, membuang yang tidak perlu dan mengorganisasikannya untuk bisa ditonjolkan persoalanpersoalan pokoknya. Reduksi data atau proses transformasi ini berlanjut terus sesudah penelitian lapangan, sampai laporan akhir secara lengkap tersusun.

\section{Penyajian Data}

Pemaparan data yang telah direduksi disajikan (material display) dalam bentuk bahan yang diorganisir dengan membuat ringkasan struktur, jaringan atau sinopsis, dengan teks - dan tidak menekankan penuangan dalam kotakkotak. Penyajian data dalam penelitian ini dilakukan dengan cara menggunakan table, bagan (chart) dan kumpulan kalimat. Penggunaan tabel untuk mendiskripsikan keadaan dan jumlah pedagang asongan, begitu juga untuk mengkategorikan jawaban responden sesuai dengan permasalahan yang diteliti. Bagan dan kumpulan kalimat untuk mendiskripsikan jawaban respondent yang diwawancarai sesuai dengan kelompok responden. Semuanya dirancang guna menggabungkan informasi yang tersusun dalam suatu bentuk yang padu dan mudah diraih, dengan demikian peneliti dapat melihat apa yang terjadi dan menarik kesimpulan yang tepat. Penyajian data atau display data dimaksudkan sebagai sekumpulan informasi tersusun yang memberikan kemungkinan adanya penarikan kesimpulan dan pengambilan tindakan.

\section{Menarik Kesimpulan/Verifikasi}

Penarikan keseimpulan merupakan satu kegiatan dari konfigurasi yang utuh selama penlitian berlangsung. Sedangkan verifikasi merupakan kegiatan pemikiran kembali yang melintas dalam pemikiran penganalisis selama peneliti mencatat, atau suatu tinjauan ulang pada catatan-catatan lapanagn atau peninjauan kembali serta tukar pikiran di antara teman sejawat untuk mengembangkan "kesempatan intersubyektif", dengan kata lain makna yang muncul dari data harus diuji kebenarannya, kekokohannya dan kecocokannya (validitasnya).

Verifikasi dalam penelitian dilakukan secara kontinyu sepanjang penelitian verifikasi oleh peneliti maksudkan untuik menganalisis dan mencari makna dari informasi yang dikumpulkan dengan mencari tema, pola hubungan, permasalahan yang muncul, hipotesa dan disimpulkan secara tentatif, sehingga terbentuk proposisi tertentu yang bisa mendukung teori ataupun penyempurnaan teori. 
Peneliti dalam hal melakukan penafsiran terhadap makna dari display data dengan mencatat keteraturan, pola, penjelasan, konfigurasi yang mungkin serta proposisi. Sebagaimana reduksi dan display data, maka verifikasi ini juga berlangsung sebelum, selama dan sesudah pengupulan data, sehingga membentuk hubungan siklus yang interaktif.

\section{HASIL PENELITIAN DAN PEMBAHASAN}

\section{Kondisi Geografis}

Kecamatan Blimbing Malang salah satu kecamatan kelurahan dari 5 kecamatan yang ada di Kota Malang. Kecamatan ini mengalami dinamika perkembangan yang sangat bagus bahkan sempat mencatatkan nama sebagai kecamatan berprestasi di Kota Malang. Secara geografis kecamatan Blimbing terletak di bagian barat kota Malang dengan luas wilayah 17,76 $\mathrm{km} 2$, sebagian wilayahnya dilalui oleh sungai brantas. Kecamatan ini terletak antara $112^{\circ} 63^{\prime}-112^{\circ} 65^{\prime}$ BT dan $7^{\circ} 92^{\prime}-7^{\circ} 98^{\prime} \mathrm{LS}$, suhu udara ratarata $24^{\circ} \mathrm{C}$ dengan ketinggian rata-rata 400-467 meter persegi dari permukaan air laut. termasuk daerah perkotaan yang tidak terdapat pegunungan, datar sampai berombak $100 \%$. Batas administratif kecamatan Blimbing adalah: Sebelah Utara Kecamatan Singosari Kabupaten Malang, Sebelah Timur Kecamatan Kedungkandang dan Kecamatan Pakis Kabupaten Malang, Sebelah Selatan Kecamatan Lowokwaru dan Kecamatan Klojen, Sebelah Barat Kecamatan Lowokwaru.

\section{Keadaan Administrasi Pemerintahan}

Tabel 1. Keadaan Administrasi Pemerintahan

\begin{tabular}{clcc}
\hline & Kelurahan & $\begin{array}{c}\text { Luas Wilayah } \\
(\mathbf{k m 2})\end{array}$ & $\begin{array}{c}\text { \% Luas Terhadap } \\
\text { Luas Kecamatan }\end{array}$ \\
\hline \multicolumn{1}{c}{$(1)$} & $(2)$ & $(3)$ \\
1 & Jodipan & 0,49 & 2,76 \\
2 & Polehan & 1,01 & 5,69 \\
3 & Kesatrian & 1,45 & 8,16 \\
4 & Bunulrejo & 1,84 & 10,36 \\
5 & Purwantoro & 2,29 & 12,89 \\
6 & Pandanwangi & 3,98 & 22,41 \\
7 & Blimbing & 1,10 & 6,19 \\
8 & Purwodadi & 1,58 & 8,90 \\
9 & Polowijen & 1,35 & 7,60 \\
10 & Arjosari & 1,16 & 6,53 \\
11 & Balearjosari & 1,51 & 8,50 \\
\hline & Kecamatan & $\mathbf{1 7 , 7 6 \%}$ & $\mathbf{1 0 0 , 0 0}$ \\
& Blimbing & & \\
\hline
\end{tabular}

Sumber: Kantor Kecamatan Blimbing 
Jarak tempuh dari Kelurahan ke Ibukota Kecamatan di Kecamatan Blimbing, sangat variatif, paling dekat adalah kelurahan Polowijwn dan Arjosari dengan jarak $0,50 \mathrm{~km}$, dan paling jauh adalah kelurahan Jodipan dengan jarak $8 \mathrm{~km}$.

Tabel 2. Jarak dari Kelurahan Ke Ibukota Kecamatan di Kecamatan Blimbing, 2015

\begin{tabular}{llc}
\hline \multicolumn{1}{c}{ Kelurahan } & $\begin{array}{c}\text { Luas Wilayah } \\
(\mathbf{k m 2})\end{array}$ \\
\hline 1 & Jodipan & 8,00 \\
2 & Polehan & 7,00 \\
\hline 3 & Kesatrian & 6,00 \\
4 & Bunulrejo & 4,00 \\
\hline 5 & Purwantoro & 2,50 \\
\hline 6 & Pandanwangi & 2,00 \\
\hline 7 & Blimbing & 2,00 \\
\hline 8 & Purwodadi & 1,50 \\
\hline 9 & Polowijen & 0,50 \\
10 & Arjosari & 0,50 \\
11 & Balearjosari & 0,70 \\
\hline
\end{tabular}

Sumber : Kantor Kecamatan Blimbing

Dari 11 Kelurahan terdapat 923 RT dan 127 RW. Berdasarkan klasifikasi dari kemampuan kelurahan dalam membangun wilayah tercatat bahwa seluruh kelurahan masuk dalam kategori kelurahan Swasembada, yang berarti bahwa seluruh kelurahan yang ada telah mampu menyelenggarakan pemerintahan dengan mandiri. Berdasarkan data daro Kecamatan Blimbing, tercatat 132 PNS yang tersebesar di Kantor Kecamatan dan 11 Kelurahan.

\section{Kondisi Demografi}

Jumlah penduduk Kecamatan Blimbing sebanyak 177.729 jiwa, atau $20,88 \%$ dari jumlah pendududk kota Malang. Jumlah penduduk terbanayak peringkat empat setelah Kecamatan Kedungkandang, Kelurahan Pandanwangi merupakan keluarahan dengan jumlah penduduk paling banyak yaitu, 29.542 jiwa. Sedangkan jumlah penduduk paling sedikit adalah Kelurahan Balearjosari yaitu 8.275 jiwa.

Dilihat dari ratio jenis kelamin, maka diketahui bahawa ratio jenis kelamin Kecamatan Blimbing sebesar 96,15 persen yang dapat dartikan bahwa dalam 100 penduduk perempuan terdapat 96 penduduk laki-laki, yang berarti bahwa penduduk perempuan lebih banyak dari laki-laki. Terkecuali kelurahan Kesatrian yang memiliki ratio jenis kelamin tertinggi yaitu 107,49 \% yang berarti bahwa dalam 100 penduduk perempuan terdapat 107 penduduk laki-laki. 
Tabel 3. Jumlah Penduduk dan Rasio Jenis Kelamin menurut Kelurahandi Kecamatan Blimbing, 2015

\begin{tabular}{llcccc}
\hline Kelurahan & Laki-laki & Perempuan & $\begin{array}{c}\text { Laki Laki }+ \\
\text { Perempuan }\end{array}$ & $\begin{array}{c}\text { Rasio } \\
\text { Jenis } \\
\text { Kelamin }\end{array}$ \\
\hline \multicolumn{1}{c}{$(1)$} & $(2)$ & $(3)$ & $(4)$ & $(5)$ \\
1 & Jodipan & 5.854 & 5.850 & 11.074 & 100,07 \\
2 & Polehan & 8.754 & 8.820 & 17.574 & 99,25 \\
3 & Kesatrian & 5.669 & 5.274 & 10.943 & 107,49 \\
4 & Bunulrejo & 13.022 & 12.557 & 25.579 & 103,70 \\
5 & Purwantoro & 13.238 & 14.090 & 27.328 & 93,95 \\
6 & Pandanwangi & 14.659 & 14.883 & 29.542 & 98,49 \\
7 & Blimbing & 4.152 & 4.610 & 8.762 & 90,07 \\
8 & Purwodadi & 8.671 & 8.978 & 17.649 & 96,58 \\
9 & Polowijen & 5.280 & 5.875 & 11.155 & 89,87 \\
10 & Arjosari & 4.618 & 4.600 & 9.128 & 100,39 \\
11 & Balearjosari & 4.119 & 4.156 & 8.275 & 99,11 \\
\hline Kecamatan & $\mathbf{8 8 . 0 3 6}$ & $\mathbf{8 9 . 6 9 3}$ & $\mathbf{1 7 7 . 7 2 9}$ & $\mathbf{9 8 , 1 5}$ \\
Blimbing & & & & \\
\hline Sumbr: Proyeksi Pend & & &
\end{tabular}

Sumber: Proyeksi Penduduk Indonesia, 2010-2035

Dilihat dari usia produktif penduduk, maka dapat disebutkan bahwa Sebagian besar warga Blimbing adalah usia produktif, yakni usia 20 tahun sampai dengan usia 60 tahun sebanyak 105.286 jiwa, dari total penduduk kecamatan Blimbing sebesar 177.729 jiwa.

Tabel 4. Jumlah Penduduk Berdasarkan Kelompok Umur dan Jenis Kelamin di Kecamatan Blimbing, 2015

\begin{tabular}{cccc}
$\begin{array}{c}\text { Kelompok } \\
\text { Umur }\end{array}$ & $\begin{array}{c}\text { Laki- } \\
\text { laki }\end{array}$ & Perempuan & $\begin{array}{c}\text { Laki Laki + } \\
\text { Perempuan }\end{array}$ \\
\hline$(1)$ & $(2)$ & $(3)$ & $(4)$ \\
$0-4$ & 7.275 & 6.783 & 14.058 \\
$5-9$ & 7.159 & 6.599 & 13.758 \\
$10-14$ & 6.596 & 6.453 & 13.049 \\
$15-19$ & 7.139 & 7.727 & 14.866 \\
$20-24$ & 8.102 & 7.707 & 15.809 \\
$25-29$ & 7.810 & 7.289 & 15.099 \\
$30-34$ & 7.611 & 7.320 & 14.931 \\
$35-39$ & 6.933 & 7.102 & 14.035 \\
$40-44$ & 6.604 & 6.915 & 13.519 \\
$45-49$ & 6.013 & 6.482 & 12.495 \\
$50-54$ & 5.113 & 5.696 & 10.809 \\
$55-59$ & 4.096 & 4.493 & 8.589 \\
$60-64$ & 2.984 & 3.009 & 5.993
\end{tabular}




\begin{tabular}{cccc}
$65-69$ & 1.984 & 2.248 & 4.232 \\
$70-74$ & 1.368 & 1.662 & 3.030 \\
$75+$ & 1.249 & 2.208 & 3.457 \\
\hline Jumlah & $\mathbf{8 8 . 0 3 6}$ & $\mathbf{8 9 . 6 9 3}$ & $\mathbf{1 7 7 . 7 2 9}$ \\
\hline
\end{tabular}

Sumber: Proyeksi Penduduk Indonesia 2010-2035

Mata pencaharian/pekerjaan dari penduduk Kecamatan Blimbing sebagian besar adalah Wiraswasta / pedagang, urutan kedua adalah Karyawan (Pegawai Negeri Sipil, ABRI, Pegawai Swasta). Urutan ketiga adalah buruh bangunan dan berikutnya adalah buruh industri. Jumlah keluarga pada tahun 2015 di Kecamatan Blimbing sebanyak 2.363 keluarga, sebanyak 91,46\% merupakan keluarga sejahtera, sedangkan sisanya sebesar 8,54\% merupakan keluarga pra sejahtera

\section{Pendidikan}

Lembaga pendidikan yang ada di wilayah Kecamatan Blimbing terbilang banyak, mulai dari tingkat Taman Kanak-Kanak / Raudhatul Athfal sampai dengan tingkat Perguruan Tinggi, sehingga dapat digambarkan bahwa kesempatan untuk mengecam pendidikan bagi warga Blimbing sangat tinggi. Berdasarkan data yang diperoleh peneliti, daya tampung lembaga pendidikan paling banyak adalah di Sekolah Dasar, kemudian SMP dan Sekolah Menengah Kejuruan. Untuk mengetahui keadaan lembaga pendidikan dan daya tampung di kecamatan Blimbing disajikan tabel sebagai berikut:

Tabel 5. Jumlah Sekolah, Murid, Guru, dan Rasio Murid-Guru di Kecamatan Blimbing, 2015

\begin{tabular}{lcccc}
\hline \multicolumn{1}{c}{ Jenjang Pendidikan } & Sekolah & Murid & Guru & $\begin{array}{c}\text { Rasio } \\
\text { Murid } \\
\text {-Guru }\end{array}$ \\
\hline Sekolah Dasar (SD) & 58 & 16.541 & 918 & 17,99 \\
Madrasah Ibtidaiyah (MI) & 5 & 1.217 & 61 & 19,95 \\
Sekolah Menengah Pertama (SMP) & 22 & 7.092 & 529 & 13,41 \\
Madrasah Tsanawiyah (MTs) & 2 & 542 & 34 & 15,94 \\
Sekolah Menengah Atas (SMA) & 6 & 319 & 107 & 2,98 \\
Madrasah Aliyah Negeri (MAN) & 1 & 23 & 16 & 1,44 \\
Roudlotul Athfal & 15 & 1.255 & 113 & 11,11 \\
Sekolah Menengah Kejuruan & 1 & 4.539 & 408 & 11,13 \\
(SMK) & & & & \\
\hline Sumb
\end{tabular}

Sumber: Kantor Kecamatan Blimbing

Data tersebut di atas belum terhitung warga yang bersekolah di wilayah kecamatan yang ada di sekitar Kecamatan Blimbing. Termasuk juga data tentang warga yang menempuh pendidikan di Perguruan Tinggi. 


\section{Kehidupan Ekonomi (Perdagangan)}

Salah satu pilar utama penopang ekonomi adalah sektor perdagangan. Oleh karenanya tentu fasilitas berupa sarana dan prasarana sektor ini perlu mendapat perhatian serius. Pasar tradisional merupakan salah satu bentuk pasar nyata dimana barang yang diperjualbelikan bisa dipegang oleh pembeli dan memungkinkan terjadinya tawar menawar secara langsung antara penjual dan pembeli.

Jumlah pasar di kecamatan Blimbing pada tahun 2015 tercatat dua (2) unit yang terdiri dari pasar Blimbing dan pasar Bunul. Dua pasar yang ada di kecamatan ini menampung sebanayak 2.027 pedagang yang menggunakan los/emper, dan sebanyak 152 pedagang yang berjualan dengan menggunakan bedak dan sisanya sebanyak 21 pedagang Kaki Lima (PKL). Untuk mendapatkan gambaran tentang keadaan pasar di kecamatan Blimbing, disajikan tabel sebagai berikut:

\section{Tabel 6. Jumlah Unit Perdagangan menurut Jenis Tempat Berjualan di Pasar di Kecamatan Blimbing, 2015 Tempat Jualan Jumlah Tempat Usaha/Perdagangan}

1. Bedak

\begin{tabular}{ll}
\hline Unit & 218 \\
\hline Pedagang & 152
\end{tabular}

2. Los/Emper

Unit 2.464

\begin{tabular}{clc} 
& Pedagang & 2.027 \\
\hline 3. & PKL & 21 \\
\hline
\end{tabular}

Kemudian untuk mengetahui berapa banyak unit dan pedagang yang ada di Pasar Blimbing (yang menjadi lokasi penelitian) dan Pasar Bunul disajikan tabel sebagai berikut:

Tabel 7. Jumlah Unit dan Pedagang menurut Jenis Pasar di Kecamatan Blimbing, 2015

\begin{tabular}{lccccc}
\hline \multicolumn{1}{c}{ Pasar } & \multicolumn{2}{c}{ Bedak } & \multicolumn{2}{c}{ Los/Emper } & PKL \\
& Unit & Pedagang & Unit & Pedagang & \\
\hline $\begin{array}{l}\text { Pasar } \\
\text { Blimbing }\end{array}$ & 116 & 103 & 2.134 & 1.804 & - \\
\hline Pasar Bunul & 102 & 49 & 330 & 223 & 21 \\
\hline
\end{tabular}




\begin{tabular}{llllll}
\hline Jumlah & 218 & 152 & 2.464 & 2.027 & 21
\end{tabular}

Sumber : Dinas Pasar Kota Malang

Tabel 7 menunjukkan bahwa dari dua pasar yang ada di kecamatan Blimbing, pasar Blimbing lah yang menampung pedagang paling banyak yaitu sebanyak 1.804 pedagang. Jumlah ini merupakan potensi besar dalam melakukan transaksi jualbeli untuk masyarakat kecamatan Blimbing dan sekitarnya. Belum lagi kalau dianalisis secara geografis, letak pasar Blimbing yang sangat strategis bagi untuk masyarakat Malang dan juga strategis bagi masyarakat di luar kota, karena pasar ini berada di jalan utama untuk masuk dan keluar dari Kota Malang.

\section{Analisis Data dan Pembahasan Aplikasi Syar'i dalam Kendali Bisnis}

Struktur Sosial masyarakat Blimbing sebagian besar masih bertahan dengan pola kehidupan lama, yaitu pola komunikasi yang menonjolkan rasa ketergantungan diantara anggota masyarakat. Pola kehidupan seperti ini, merupakan hubungan sosial masyarakat yang didasarkan pada ikatan-ikatan ketetanggaan dan kekeluargaan. Dalam konteks kehidupan sosial masyarakat Blimbing yang tingkat ketergantungannya / kohesivitasnya tinggi tersebut tidak mempunyai hubungan yang begitu rigid dengan adanya homogenitas yang ada didalamnya. Hal ini juga berlangsung dalam hubungan perdagangan baik antar sesama pedagang kaki lima / Asongan maupun dalam transaksi jual beli antara pedagang dengan konsumen (pembeli).

Berikut ini akan disajikan bagaimana aplikasi syari'at Islam sebagai kendali bisnis (Studi Kasus Pedagang Kaki Lima / Asongan di Pasar Beliming Malang). Terdapat empat (4) orientasi Syari'at Islam sebagai kendali bisnis yang akan diteliti, yaitu: (1) Target hasil: profit-materi dan benefit-non materi, (2) Pertumbuhan, terus meningkat. (3) Keberlangsungan, dalam kurun waktu selama mungkin (4) Keberkahan atau keridhaan Allah.

\section{Target hasil : profit-materi dan benefit-non materi}

Secara teoritis, target atau tujuan usaha tidak harus hanya untuk mencari profit (qimah madiyah atau nilai materi) setingginya, tetapi harus dapat memperoleh dan memberikan nilai benefit (keuntungan atau manfaat) non materi kepada internal organisasi perusahaan (pedagang Kaki Lima dan pedagang Asongan), dan eksternal (lingkungan), seperti terciptanya suasana persaudaraan, kepedulian sosial, dan sebagainya.

Berdasarkan hasil wawancara terhadap para Pedagang Kaki Lima dan Pedagang Asongan di sekitar Pasar Blimbing Malang, diketahui bahwa ternyata para pedagang dalam menjalankan usahanya tidak semata-mata mendapatkan keuntungan materi yang setinggi-tingginya, tetapi mereka juga 
ingin memperoleh kepuasan yang bersifat non materi. Sebagian besar dari responden mengatakan mereka akan merasa puas kalau ternayata dalam menjalankan usaha dan hasil usaha perdagangan mereka bisa bermanfaat terhadap lingkungan sekitar dan untuk kepentingan interaksi sosial. Para pedagang bersikap ramah dan toleran terhadap sesama dan mau menjalin persaudaraan antar sesama pedagang dan masyarakat sekitar. begitu juga kerelaan mereka untuk membantu pihak tertentu yang kebetulan meminta bantuan. Sikap ini sejalan dengan prinsip Islam Ramah-tamah. Seorang pelaku bisnis, harus bersikap ramah dalam melakukan bisnis. Nabi Muhammad Saw mengatakan, "Allah merahmati seseorang yang ramah dan toleran dalam berbisnis" (H.R. Bukhari dan Tarmizi).

Pada sisi lain, tampak bahwa pedagang juga rela untuk membantu pihak tertentu yang kebetulan membutuhkan pertolongan materi, mereka ikhlas memberi sesuai kemampuan yang dimiliki demi kebaikan sesama. Kesadaran tentang signifikansi sosial kegiatan bisnis. Pelaku bisnis menurut Islam, tidak hanya sekedar mengejar keuntungan sebanyak-banyaknya, sebagaimana yang diajarkan Bapak ekonomi kapitalis, Adam Smith, tetapi juga berorientasi kepada sikap ta'awun (menolong orang lain) sebagai implikasi sosial kegiatan bisnis. Tegasnya, berbisnis, bukan mencari untung material semata, tetapi didasari kesadaran memberi kemudahan bagi orang lain dengan menjual barang. Memberi kemudahan bagi orang sesungguhnya merupakan bagian dari sikap saling tolong menolong dalam kebaikan. Allah SWT di dalam al-Quran Surat al-Maidah: 2, memerintahkan "Dan tolong menolonglah kamu dalam (mengerjakan) kebajikan dan taqwa, dan jangan tolong menolong dalam berbuat dosa dan permusuhan"

Dalam menjalankan usaha, pedagang tidak melakukan apa yang disebut dengan ihtikar, yaitu menumpuk dan menyimpan barang dalam masa tertentu, hal itu dilakukan dengan tujuan agar harganya bisa menjadi tinggi sehingga mereka memperoleh keuntungan yang besar. Perbuatan menimbun atau menyembunyikan sesuatu barang yang dibutuhkan orang akan membawa akibat buruk bagi sesama manusia, terutama mereka yang membutuhkan barang itu dalam keadaan mendadak. Rasulullah dalam Haditsnya melarang keras perilaku pedagang yang menimbun atau menyembunyikan sesuatu barang yang menjadi kebutuhan utama manusia, yang kemudian akan dijual dengan harga yang melambung tinggi sehingga bisa memperoleh keuntungan yang berlipat ganda.

\section{Pertumbuhan}

Di Dalam referensi Ekonomi Syari'ah disebutkan bahwa jika profit materi dan benefit non materi telah diraih sesuai target, perusahaan akan mengupayakan pertumbuhan atau kenaikan terus menerus dari setiap profit dan benefitnya itu. Hasil perusahaan akan terus diupayakan agar tumbuh 
meningkat setiap tahunnya. Upaya penumbuhan ini tentu dijalankan dengan koridor syariat Islam.

Penelitian ini dilakukan terhadap pedagang kaki lima dan pedagang asongan yang sudah tentu dalam pelaksanaan usahanya tidak sama dengan sebuah perusahaan. Umumnya mereka mengandalkan pengalaman mereka di dalam melaksanakan usaha dagang. Dari hasil wawancara ditemukan bahwa didalam menjalankan usaha, pedagang kaki lima dan asongan ini mengutamakan dimensi keandalan, dimana mereka selalu berusaha untuk menepati janji kepada pelanggan, ketika pelanggan memesan barang atau produk tertentu. Pedagang juga berupaya bersikap sopan santun, tampil simpatik dan mempersiapkan perlengkapan (sarana usaha) dengan menarik untuk mengesankan dan meyakinkan para pelanggan membeli dagangannya. Dalam menjajakkan dagangannya, pedagang berupaya untuk menumbuhkan rasa empati / kepedulian yang tinggi kepada pelanggan, punya daya tanggap yang bagus (keinginan untuk membantu pelanggan dengan memberikan pelayanan yang cepat. Semua itu dilakukan pedagang karena memiliki sikap ramah, lemah lembut atau kasih sayang terhadap sesama. Ajaran Islam memerintahkan untuk bersikap ramah (lemah lembut) sebagaimana difirmankan di dalam Al-Quran surat ali-Imran: 159 "Maka berkat rahmat Allah engkau (Muhammad) berlaku lemah lembut terhadap mereka. Sekiranya engkau bersikap keras dan berhati kasar, tentulah mereka menjauhkan diri dari sekitarmu. Karena itu maafkanlah mereka dan mohonkanlah ampunan untuk mereka, dan bermusyawarahlah dengan mereka dalam urusan itu. Kemudian Apabila engkau telah membulatkan tekad, maka bertaqwalah kepada Allah. Sungguh Allah mencintai orangorang yang bertawakkal"

Nabi Muhammad Saw mengatakan, "Allah merahmati seseorang yang ramah dan toleran dalam berbisnis” (H.R. Bukhari dan Tarmizi).

\section{Keberlangsungan}

Belum sempurna orientasi manajemen suatu perusahaan bila hanya berhenti pada pencapaian target hasil dan pertumbuhan. Karena itu perlu diupayakan terus agar pertumbuhan target hasil yang telah diraih dapat dijaga keberlangsungannya dalam kurun waktu yang cukup lama. Sebagaimana upaya pertumbuhan, setiap aktivitas untuk menjaga keberlangsungan tersebut juga dijalankan dalam koridor syariah. Upaya menjaga keberlangsungan ini meliputi: penyedian modal usaha, modal sosial ( jaringan, kerjasama dan kepercayaan), tenaga kerja yang dilibatkan dalam usaha, jumlah produksi dan sistem pemasaran.

Modal usaha merupakan hal pokok yang harus mendapat perhatian setiap usaha perdagangan, apakah itu usaha perdagangan yang besar ataupun yang 
kecil. Sudah tentu termasuk juga di dalamnya pedagang asongan atau pedagang kaki lima. Berdasarkan hasil interview yang dilakukan terhadap para pedagang asongan / kaki lima di sekitar pasar Belimbing sebagian besar menyatakan bahwa modal untuk usaha mereka adalah dari hasil usaha simpanan mereka sendiri, sebagian kecil dari mereka mengatakan memperoleh pinjaman dari orang lain dengan sistem bagi hasil. Sebagian kecil mengakui bahwa untuk memperoleh modal usaha mereka harus berhubungan dengan para rentenir yang ada di pasar Belimbing. Modal yang dibutuhkan antara Rp.300.000,- sampai dengan Rp. 1.500.000,- untuk sekali produksi. Dari aspek syari'ah Islam dapat di katakan bahwa dalam hal penyertaan modal usaha para pedagang bersikap sesuai dengan tuntunan syar'i karena mereka kenyataannya mereka hanya mau menerima modal yang didasarkan atas kesepakatan bagi hasil sesuai dengan aqad pada saat peminjaman modal dan ketika mereka tidak mau berhubungan dengan para rentenir dalam peminjaman modal usaha, paling tidak mereka menjaga diri mereka dari perbuatan riba yang dilarang oleh Allah SWT sebagaimana firmannya: "Allah menghalalkan jual beli dan mengharamkan riba" (alBaqarah : 275) begitu juga Firman Allah "Allah memusnahkan riba dan menyuburkan sedeqah" (al-Baqarah: 276)

Dalam hal modal sosial yang meliputi Jaringan usaha, kerjasama dan kepercayaan, apara pedagang asongan atau kaki lima mengakui bahwa mereka menjaga hubungan kerja yang baik dengan rekanan yang terkait dengan usaha mereka dengan menjalin kerja sama yang saling menguntungkan dan menjunjung tinggi nilai kepercayaan yang diberikan kepada sesama guna menjaga kelangsungan usaha mereka. Dari hasil wawancara dapat diketahui bahwa walaupun beberapa diantara mereka ini hanya menjual apa yang di produk oleh teman usaha tapi mereka bisa mempertahankan kesepakatan mereka dalam hal harga jual barang. Umumnya mereka tidak mau menjual sesuatu yang diluar harga yang disepakati dengan maksud barang cepat habis dan mereka bisa meningkatkan volume penjualan. Sikap seperti ini merupakan sikap terpuji seorang pedagang terhadap perintah menegakkan amanah atau kepercayaan sebagaimana diperintahkan dalam syari'at Islam "Allah menyuruhmu menyampaikan amanat kepada yang berhak menerimanya" (al-Quran surat Al-Nisa ; 58). Begitu juga firman Allah dalam surat al-Anfal: 27 "Wahai orang-orang yang beriman janganlah kamu mengkhianati Allah dan Rasul dan juga jangan kamu mengkhianati amanat yang dipercayakan kepadamu, sedang kamu mengetahui”.

Walaupun demikian terdapat dua orang pedangan yang mengakui secara jujur bahwa meraka pernah berkhianat terhadap teman se profesi atau jaringan mereka, dan ternyata perbuatan itu membawa penderitaan tersendiri bagi pelaku karena merasa sselalu dihantui oleh dosa dan selalu menghindar 
dari orang yang dikhianati ketika melakukan aktivitas usaha. Merasa tidak tenang dan injoy dalam bekerja dan lama kelamaan mereka sadar bahwa mengkhianati amanah / merusak sebuah perjanjian itu membuat orang tidak tenang atau tidak bahagia. Sikap ini sejalan dengan firman Allah dalam surat al-Mukminun: 1- 9. Yang intinya Allah mengatakan salah satu tanda orang mukmin yang akan memperoleh kemenangan atau kebahagian adalah orang yang memelihara amanah-amanah dan janjinya. Pengaruh modal sosial tersebut memberikan hasil yang lebih baik dalam mempertahankan keberlangsungan usaha bahkan pedagang tersebut dapat mengembangkan usaha mereka.

\section{Keberkahan atau Ridha Allah}

Faktor keberkahan atau orientasi untuk menggapai ridha Allah SWT merupakan puncak kebahagiaan hidup seorang muslim. Bila ini tercapai, menandakan terpenuhinya dua syarat, diterimanya amal manusia, yakni adanya elemen niat yang ikhlas dan cara yang sesuai dengan tuntunan syari'at. Karenanya, para pengelola bisnis perlu mematok orientasi keberkahan yang dimaksud agar pencapaian segala orientasi di atas senantiasa berada dalam koridor syari'at yang menjamin diraihnya keridhaan Allah SWT. (Muhammad Ismail Yusanto, Muhammad Karebet Widjajakusuma, 2002, hal. 19-21).

Dari paparan diatas, jelaslah bahwa orientasi bisnis Islam harus didasarkan pada pengabdian kepada Allah. Hal ini sebagaimana dinyatakan di dalam alQuran Adz-Dzariyah: 56). "Dan Aku tidak menciptakan jin dan manusia melainkan agar beribadah kepada-Ku” (M.Quraish Shihab, 2009, jilid 13, hal 573)

Wawancara yang dilakukan peneliti terhadap para pedagang asongan atau kaki lima di sekitar pasar Belimbing, diketahui bahwa sebagian besar pedagang dalam menjalankan usahanya tidak semata hanya untuk mencari keuntungan yang maksimal tetapi juga untuk meraih berkah atau ridha Allah SWT, motivasi atau niat pedagang adalah karena Allah, sebagai bentuk pengabdian hamba kepada sang Pencipta. Dengan adanya niat ini maka yang muncul dari perilaku pedagang adalah berperilaku yang sesuai dengan aturan atau syri'at Allah. Walaupun memperoleh keuntungan yang sedikit tetapi mereka merasa puas terhadap hasil yang mereka capai. Sebagian besar pedagang sudah beranggapan bahwa walau sedikit yang penting halal dari pada memperoleh keuntungan yang banyak tetapi dari hasil menggelabui atau membohongi konsumen. Sedikit sekali pedagang yang mengatakan bahwa dalam bisnis mereka itu hanya untuk mencari keuntungan yang tinggi dengan melakukan berbagai cara termasuk juga cara-cara yang tidak sesuai dengan syari'at Islam. 
Berdasarkan hasil wawancara dan pengamatan peneliti maka dapat dikatakan bahwa motif atau niat para pedagang dalam usahanya adalah mencari berkah atau ridha Allah SWT. Tidak hanya semata-mata untuk memaksimalkan keuntungan, sebagaimana yang dianut oleh system ekonomi konvensional. Motif untuk mamaksimalkan keuntungan sesungguhnya tidak di larang di dalam syariat Islam tetapi diatur atau diletakkan pada posisi yang tepat yang sesuai dengan tatacara berbisnis yang islami. Para pedagang dalam menjalankan usahanya Motif dalam produksi dalam konteks Islam bukanlah pada memaksimilisasi kepuasan dan maksimalisasi keuntungan yang menjadi pendorong utama sekaligus tujuan dari keputusan ekonomi dalam pandangan ekonomi konvensional bukannya salah ataupun dilarang di dalam Islam. Islam ingin mendudukkannya pada posisi yang benar, yakni semua itu dalam rangka maksimalisasi dan keuntungan di akhirat ( Mustafa Edwin Nasution, dkk, 2006, hal. 102).

Pandangan ini sesuai dengn apa yang diisyaratkan Allah di dalam firmanNya Surat Hud ayat 15-16: "Baraangsiapa yang menghendaki kehidupan dunia dan perhiasannya, niscaya niscaya kami sempurnakan bagi mereka pekerjaan-pekerjaan mereka di sana dan mereka di sana tidk akan dirugikan. Itulah orang-orang yang tiada bagi mereka di akhirat kecuali neraka dan lenyaplah apa yang telah mereka usahakan di sini, dan siasialah apa yang senantiasa mereka kerjakan” (M.Quraish Shihab, 2009, jilid 5, hal 573)

Sikap para pedagang asongan atau kaki lima yang tidak ingin mengecewakan para konsumen adalah sesuatu yang terpuji yang mana ni menjadi bagian yang sangat penting dalam etika berbisnis yang dipraktekkan oleh Rasulullah SAW. Praktek bisnis yang sudah dicontohkan oleh Rasullah SAW terhadap ummatnya mengantarkan Rasulullah SAW mendapat kepercayaan yang tinggi dengan gelar Al-Amin (yang dapat dipercaya): praktek tersebut antara lain:

Jujur, merupakan sifat utama dan etika islam yang luhur. Jujur meruakan motivator yang abadi dalam budi pekerti dan perilaku seorang muslim; sebagai salah satu sarana untuk memperbaiki amalnya, menghaus dosadosanya, dan sarana untuk bisa masuk ke surga. Seorang pebisnis, jika dalam mendistribusikan barang dagangannya selalu disertai dengan sumpahmeskipun dia jujur- maka dia menjadikan Allah dalam sumpahnya menghalangi pelaku bisnis berbuat kesalahan dalam berdagang. Dianatar bentuk kejujuran adalah, seorang pebisnis harus menjaga dan mencintai mereka sebagaimana dia mencintai dirinya sendiri.

Amanah, Islam menginginkan pebisnis mempunyai hati nurani yang mulia sehingga bisa menjaga hak-hak Allah dan hak-hak manusia, dan bisa memproteksi muamalahnya dari tingkah laku yang mendorong untuk 
membuat remeh dan lalai. Dengan demikian, Islam mewajibkan pebisnis mempunyai sikap amanah dalam dirinya sendiri dan orang lain. Amanah mendorong seseorang untuk bisa menjaga hak dan memelihara kehinaan. Hal itu tidak akan terjadi kecuali amanah sudah melekat erat dalam nurani atau menjadi milik jiwa dan perasaannya.

Toleransi, Toleransi adalah kunci rezeki dan jalan kehidupan yang mapan. Diantara manfaat toleransi adalah mudah berinteraksi, mempermudah muamalah, dan mempercepat berputarnya modal. Rasulullah SAW bersabda : "Allah mengasihi seseorang yang toleran ketika berdagang, ketika membeli, dan ketika meminta haknya.” (HR. Bukhari)

\section{KESIMPULAN DAN SARAN Kesimpulan}

Para pedagang dalam menjalankan usahanya tidak semata-mata mendapatkan keuntungan materi yang setinggi-tingginya, tetapi mereka juga ingin memperoleh kepuasan yang bersifat non materi. Hal ini ditunjukkan dengan adamnya rasa puas kalau ternayata dalam menjalankan usaha bisa bermanfaat terhadap lingkungan sekitar dan untuk kepentingan interaksi sosial. bersikap ramah dan toleran terhadap sesama dan mau menjalin persaudaraan antar sesama pedagang dan masyarakat sekitar. Mereka juga rela untuk membantu pihak tertentu yang kebetulan meminta bantuan. Pedagang tidak melakukan apa yang disebut dengan ihtikar, yaitu menumpuk dan menyimpan barang dalam masa tertentu, guna memperoleh keuntungan yang tinggi.

Umumnya mereka mengandalkan pengalaman mereka di dalam melaksanakan usaha dagang, pedagang kaki lima dan asongan ini mengutamakan dimensi keandalan, dimana mereka selalu berusaha untuk menepati janji kepada pelanggan, ketika pelanggan memesan barang atau produk tertentu. Pedagang juga berupaya bersikap sopan santun, tampil simpatik, punya rasa empai dan mempersiapkan perlengkapan (sarana usaha) dengan menarik untuk mengesankan dan meyakinkan para pelanggan membeli dagangannya.

Para pedagang agar hasil yang telah diraih dapat dijaga keberlangsungannya dalam kurun waktu yang cukup lama. Setiap aktivitas untuk menjaga keberlangsungan tersebut juga dijalankan dalam koridor syariah. Upaya menjaga keberlangsungan ini meliputi: penyedian modal usaha mereka tidak mau terlibat dengan praktek rentenir di sekitar pasar Belimbing yang bisa membawa mereka pada perbuatan riba, begitu juga modal sosial ( jaringan, kerjasama dan kepercayaan), 


\section{Saran}

Saran dalam penelitian ini adalah: (1) Perlu dilakukan pembinaan keagamaan bagi para pedagang asongan atau kaki lima di sekitar pasar Belimbing Malang oleh pihak terkait guna meningkatkan kesadaran keagamaan dan pada akhirnya memiliki kedekatan dengan Allah SWT. (2) Bagi pemerintah harus memprotek praktek-praktek rentenir yang beroperasi di Pasar Belimbing Malang dalam rangka membantu melepaskan beban pembiayaan bagi pedagang yang menggunakan jasa rentenir. Sekaligus juga menumbuhkan suasana Islami di dalam berbisnis. Paling tidak mencegah pedagang untuk tidak terjerumus dalam kejahatan riba.

\section{DAFTAR PUSTAKA}

A.Karim Adi Warman, Ekonomi Mikro Islami, PT RajaGrafindo Persada, Jakarta, 2015

Matthew B. Miles dan A. Michael Huberman, Analisis Data Kualitatif, Jakarta, Penerbit Universits Indonesia, 2009.

Moleong Lexy J., Metodologi Penelitian Kualitatif, Bandung, PT Remaja Rosdakarya, 2000 2011 Metodologi Penelitian Kualitatif, Bandung, Remaja Rosdakarya,

Moh. Nazir, Metode Penelitian, Bogor, Ghalia Indonesia, 2005.

Mustafa Edwin Nasution, et al. Pengenalan Eksklusif Ekonomi Islam, Jakarta, PRENAMEDIA GROUP, 2006.

Yafie Ali, Menggagas Fiqih Sosial, Jakarta, Mizan, 1994.

Syihab M. Quraish, Wawasan Al-Quran, Jakarta, Mizan, 1996. , Tafsir Al-Mishbah, Ciputat, Lentera Hati, Jilid 5, 2009. , Tafsir Al-Mishbah, Ciputat, Lentera Hati, Jilid 13, 2009.

Yusanto Muhammad Ismail dan Muhammad Karebet Widjajakusuma, Menggagas Bisnis Islam, GEMA INSANI, Jakarta, 2002.

Yafie Ali, Menggagas Fiqih Sosial, Jakarta, Mizan, 1994 
DAFTAR PUSTAKA 


\section{DAFTAR PUSTAKA}

A.Karim Adi Warman, Ekonomi Mikro Islami, PT RajaGrafindo Persada, Jakarta, 2015

Matthew B. Miles dan A. Michael Huberman, Analisis Data Kualitatif, Jakarta, Penerbit Universits Indonesia, 2009

Moleong Lexy J., Metodologi Penelitian Kualitatif, Bandung, PT Remaja Rosdakarya, 2000 2011 Metodologi Penelitian Kualitatif, Bandung, Remaja Rosdakarya,

Moh. Nazir, Metode Penelitian, Bogor, Ghalia Indonesia, 2005

Mustafa Edwin Nasution, et al. Pengenalan Eksklusif Ekonomi Islam, Jakarta, PRENAMEDIA GROUP, 2006

Yafie Ali, Menggagas Fiqih Sosial, Jakarta, Mizan, 1994

Syihab M. Quraish, Wawasan Al-Quran, Jakarta, Mizan, 1996 , Tafsir Al-Mishbah, Ciputat, Lentera Hati, Jilid 5, 2009 Tafsir Al-Mishbah, Ciputat, Lentera Hati, Jilid 13, 2009

Yusanto Muhammad Ismail dan Muhammad Karebet Widjajakusuma, Menggagas Bisnis Islam, GEMA INSANI, Jakarta, 2002

Yafie Ali, Menggagas Fiqih Sosial, Jakarta, Mizan, 1994 
